\title{
SCIENTIFIC AND TECHNOLOGICAL ACTIVITIES OF TNC: CURRENT TRENDS AND PROSPECTS
}

\author{
Nataliia Bezrukova*, PhD (Economics), Associate Professor \\ Vitalii Svichkar**, PhD (Economics) \\ Ruslan Solohub, Master-Student \\ National University «Yuri Kondratyuk Poltava Polytechnic».
}

* ORCID 0000-0003-3376-6718
* ORCID 0000-0001-8554-1313

(C) Bezrukova N., 2020.

(C) Svichkar V., 2020.

(C) Solohub R., 2020.

Стаття отримана редакиією 11.09 .2020 р.

The article was received by editorial board on 11.09.2020

Introduction. At the turn of the XX-XXI centuries, humanity has entered an innovative era, characterized by rapid growth of change in all spheres of social life. This is a time of knowledge-intensive technologies, progress of basic sciences, large-scale scientific and technological projects. Under such conditions, the source of modern development of society and human activity becomes innovation, and accordingly, innovation becomes an important tool for all radical changes in human development and the economic system in general.

The scientific and technological development of corporations is a crucial prerequisite for ensuring their profitable activities. However, many companies are characterized by unpreparedness for technological change, the emergence of situations of uncontrollability in the innovation sphere, contradictions between technological cycles, mismatch between elements of corporate culture in the context of building and effective use of intellectual capacity, which often leads to loss of the position in global markets. Only a few of the multinational corporations manage to maintain the high pace and efficiency of scientific and technological progress.

The study of building and realizing the scientific and technological potential in leading transnational corporations is relevant for Ukrainian companies at the stages of their internationalization and ensuring international competitiveness in the context of forming a national innovative model of development. Domestic enterprises pay insufficient attention to the formation of effective mechanisms of innovation management. Simplified approaches to managing the technological development of corporations not only narrow the opportunities and limit the pace of economic growth in Ukraine, but also threaten a systemic gap in the effective use of scientific and technological factors in general.

Review of the recent research and publications sources. The influence of scientific and technological factors on the activities of corporations is reflected in numerous studies. Among them are the fundamental works by foreign and Ukrainian scientists:

M. Porter [1], Ph. Kotler [2], R. Nelson [3], L. Antoniuk [4], V. Biloshapka [4], O. Cherneha [5] and others devoted themselves to the study of the peculiarities of the multinational corporations activities and the formation of their competitive advantages. M. Porter argued that success of the firm in the market depends on of the scientific and technological activities. The choice of the latter is influenced by the peculiarities of the competition and the position of the firm in this industry [1]. Ph. Kotler and K. Keller devoted their work to the analysis of the scientific and technological competitive advantages on the national and foreign markets [2]. R. Nelson examined the scientific and technological activities firm's through innovative component [3]. Representing school of global competitive leadership O. Cherneha [5] investigated the problems and prospects of the scientific and technological activities of TNCs in global economy. The problems of management effectiveness of the scientific and technological activities of TNCs as an element of ensuring their international competitiveness were examined in the works of V. Biloshapka [4]. But given the 
dynamism of the global economy, the sources of competitive advantages of the scientific and technological activities of TNCs are constantly changing, which needs further analysis.

Task statement is to analyze current trends and prospects for the development of scientific and technological activities of transnational corporations.

Basic material and results. Maintaining their positions in international markets by transnational corporations is impossible without the introduction of new technologies aimed at developing their competitive advantages both in the direction of reducing costs and in the direction of adding value to products and services. The global nature of competition not only makes innovation more significant for TNCs, but also necessitates the search for new ways to innovate.

In today's environment, truly advanced are those companies that are able to closely monitor all market and technological trends, respond creatively to the opportunities and threats that these trends carry, constantly generate new ideas and products and use them quickly and efficiently, taking into account the global scale. The technological policy of the firm should promote a dual global goal - first, to reduce risks and survive, and secondly, to increase the efficiency of its own activities, to become more profitable.

Until recently, corporations set up their laboratories, mainly in the home country, where new products were developed, trial production was organized, market tests were conducted, and so on. In large foreign branches, as a rule, centers were opened for the adaptation of TNC products to local conditions, its certification in national markets (taking into account the requirements of local legislation, climate, possible ergonomic features, etc.). It was believed that the task of local centers is not to create innovations, but to expand the base for products already tested in the markets, thereby reducing their cost [3].

This strategy of organizing R \& D was used mainly by American TNCs, which at the beginning of the XXI century cease to be absolute innovation leaders. They are gradually being overtaken by leading TNCs from Japan and the EU. An example of such a provision is a comparison of the dynamics of R\&D expenditures in some of the world's leading companies, which is shown in Table 1 [10].

Dynamics of expenditures of individual leading TNCs on R\&D [10]

\begin{tabular}{|c|c|c|c|c|}
\hline \multirow{2}{*}{ Company } & \multicolumn{4}{|c|}{ Years } \\
\hline & 2007 & 2011 & 2015 & 2019 \\
\hline \multicolumn{5}{|c|}{ USA } \\
\hline General Motors, (bln. USD) & 8,2 & 7,2 & 6,6 & 6,96 \\
\hline Ford Motor Company, (bln. USD) & 6,5 & 5,2 & 7,2 & 5,0 \\
\hline The Boeing Company, (bln. USD) & 1,8 & 1,5 & 3,26 & 4,1 \\
\hline Microsoft Corporation, (bln. USD) & 2,6 & 6,3 & 6,58 & 8,7 \\
\hline \multicolumn{5}{|c|}{ EUROPE } \\
\hline Siemens AG (Germany), (bln. EUR) & 3,9 & 5,1 & 3,1 & 3,8 \\
\hline Sanofi (France), (bln. EUR) & 1,3 & 3,4 & 4,43 & 5,8 \\
\hline Roche Holding AG (Switzerland), (bln. EUR) & 3,7 & 4,3 & 5,9 & 4,2 \\
\hline Volkswagen AG (Germany), (bln. EUR) & 4,2 & 4,4 & 4,3 & 3,1 \\
\hline \multicolumn{5}{|l|}{ 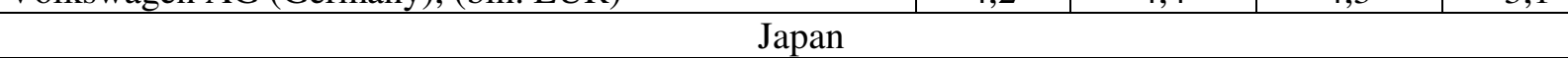 } \\
\hline Honda Motor Co., Ltd.,(bln. JPY) & $\ldots$ & 395,2 & 510,3 & 587,9 \\
\hline Toyota Motor Corporation, (bln. JPY) & 23,1 & 29,9 & 31,2 & 178,7 \\
\hline Toshiba Corporation, (bln. JPY) & 322,9 & 326,2 & 394,0 & 323,2 \\
\hline Hitachi Ltd., (bln. JPY) & 4,5 & 6,4 & 412,5 & 372,4 \\
\hline
\end{tabular}

The global nature of competition not only makes innovation more significant for TNCs, but also necessitates the search for new ways to innovate. Traditionally, most international corporations have used one of two classic types of technology policy [9:

- "center-for-global" (global center policy);

- "local-for-local" (policy of polycentrism).

Centralization of $R \& D$ is due to the following reasons:

1) the need for control by the corporation's management over the technology, which is considered as a long-term competitive advantage;

2) the need for close interaction between the development of documentation and equipment, and later - between the functions of production and development of technology; 
3) reduction of time for $R \& D$ in a rapidly changing competitive environment.

The main risk of centralized technology policy is that the result of innovation may not accurately reflect local market needs, there may also be difficulties with the introduction of new technology due to resistance from subsidiaries to make centralized decisions.

In modern conditions, despite the deepening trend of globalization in many industries, the need to take into account the peculiarities of local demand and country differences does not disappear, and often even increases.

But this type of innovation process has its downsides:

- the desire of national branches for autonomy is not always justified;

- duplication of developments already carried out in other subsidiaries of TNCs, in the case when each national branch is looking for its own solution to a common problem;

- the emergence of additional costs for R \& D [11].

Fierce and relentless competition in the global market with a high level of representation of various actors requires international monopolies, which claim the status of its influential players, to actively engage in innovation and significantly transform their technology policy. Today, the latter is increasingly gaining global features, when the processes of internationalization involved almost all stages of creation and development of new technology - from the generation of innovative ideas to the production of high-tech products and its sale in the global market. This is evidenced, in particular, by the rapid expansion of R\&D of foreign branches of TNCs in recent decades: if in 1975 the cost of American monopolies for these purposes was only 1.5 billion dollars. USA, in 2000 they reached 14.8 billion dollars. USD, and in $2018-27.5$ billion dollars. USA. In 2018, about 14\% of the funds allocated by American TNCs for R\&D were spent on research and development in research centers of their foreign branches. For Ireland, the corresponding figure was about $72 \%$, for Belgium $-56 \%$, for Sweden $-45 \%$ [8]. R\&D results obtained with the participation of foreign scientists are usually actively used by parent companies, and in some manufacturing industries pharmaceutical, chemical, instrumentation - the value of research laboratories in foreign branches of TNCs is often greater than parent companies. In addition, the affiliates themselves direct the vast majority of R\&D expenditures (about 80\%) to projects implemented for their own needs, although these studies are often associated with work carried out in other branches of the TNC and its parent company. Such intra-firm international cooperation to some extent reorients interstate technological exchange towards deepening scientific and technological cooperation between TNCs and their branches, which enhances the technological potential of the world's leading countries and provides their technological leadership in various areas of scientific and technological competition [12].

Analysis of the world economy development shows that the most profitable sectors today are focused on the production of information technology, computers and semiconductors, communications and telecommunications systems, drugs and medical equipment. Their success is based primarily on the use of previously acquired scientific knowledge and new technical and technological solutions in combination with a clear and consistent concept of doing business in the field of scientific and technological developments and their implementation.

These TNCs use research centers in many countries, where they have qualified personnel and other necessary conditions in order to improve the production of their products in accordance with local conditions of expanding markets for products and services. Thus, the leading American TNCs have about 200 research laboratories abroad in countries such as Japan, Britain, Canada, Germany [15].

The experience of developed countries shows that competitiveness is ensured by a number of conditions, the main of which are the accumulated scientific and technological potential, institutional factors of technological progress and the presence of large knowledge-intensive corporations. Therefore, the current trend of scientific and technological activities of TNCs is a new wave of mergers and acquisitions (M\&A).

The so-called period of mega-mergers began in the 90s of the twentieth century. This period of time was characterized by the growth of international M\&A operations, and combined competitors, especially British companies with American ones. Strengthening of mergers and acquisitions was observed in all industries, but the greatest development was in the field of communications, information technology, banking and financial services, the medical industry and transport.

At the beginning of the XXI century, the market of mergers and acquisitions has experienced significant growth. The companies' desire for mergers and acquisitions has grown, and the market situation has improved even more thanks to some major deals: the world's largest pharmaceutical concern Pfizer, Inc. acquired the American company Pharmacia for 57.8 billion dollars, the Italian computer, printer and 
typewriter company Olivetti bought Telecon Italia SPA for 24.4 billion dollars, the British oil and gas company BP plc acquired a consortium of Alfa Group for 7.7 billion dollars and others [8].

The lively interest of large transnational entities was also concentrated in the financial sector, pharmaceuticals, oil and gas industry and the energy sector, which can be traced in Table 2 [9].

Table 2

The largest M\&A operations of the early XXI century, billion dollars USA [9]

\begin{tabular}{|l|l|l|c|}
\hline \multicolumn{1}{|c|}{ Buyer Company } & \multicolumn{1}{|c|}{ Sphere of activity } & \multicolumn{1}{c|}{ Acquired company } & $\begin{array}{c}\text { Cost of the } \\
\text { transaction }\end{array}$ \\
\hline Pfizer, Inc. (USA) & Pharmaceutics & Wyeth (USA) & 68,0 \\
\hline $\begin{array}{l}\text { Roche Holding AG } \\
\text { (Switzerland) }\end{array}$ & $\begin{array}{l}\text { Production of } \\
\text { biological products }\end{array}$ & Genentech Inc. (USA) & 46,7 \\
\hline Lake Acquisitions Ltd. (UK) & Energy & British Energy Group PLC (UK) & 16,9 \\
\hline Enel SpA (Italy) & Energy & Endesa SA (Spain) & 13,5 \\
\hline $\begin{array}{l}\text { Mirror Lake Oil \& } \\
\text { Gas Co Ltd (Canada) }\end{array}$ & Oil and gas industry & $\begin{array}{l}\text { Addax Petroleum } \\
\text { Corp. (Switzerland) }\end{array}$ & 7,2 \\
\hline $\begin{array}{l}\text { Sumitomo Mitsui } \\
\text { Banking Corp (Japan) }\end{array}$ & Financial services & $\begin{array}{l}\text { Nikko Cordial } \\
\text { Securities Inc. (Japan) }\end{array}$ & 5,8 \\
\hline Sanofi (France) & Pharmaceutics & Merial Ltd (USA) & 4,0 \\
\hline $\begin{array}{l}\text { Korea National } \\
\text { Oil Corp (Rep. Korea) }\end{array}$ & Oil and gas industry & Harvest Energy Trust (Canada) & 3,9 \\
\hline $\begin{array}{l}\text { GlaxoSmithKline } \\
\text { PLC (UK) }\end{array}$ & Pharmaceutics & $\begin{array}{l}\text { Stiefel Laboratories } \\
\text { Inc. (USA) }\end{array}$ & 3,6 \\
\hline $\begin{array}{l}\text { Warner Chilcott } \\
\text { PLC (USA) }\end{array}$ & Pharmaceutics & $\begin{array}{l}\text { Procter \& Gamble } \\
\text { Pharmaceuticals Inc. (USA) }\end{array}$ & 3,1 \\
\hline
\end{tabular}

Most M\&A operations were carried out by North American corporations, but activity has also increased worldwide in various sectors of the economy. During this period, the Swiss pharmaceutical concern Novartis International AG for more than 28 billion dollars acquired from the Swiss corporation Nestle S.A. American eye care manufacturer Alcon, and Kraft Foods Inc. for 19.5 billion dollars bought the British confectionery company Cadbury plc., General Motors Corporation acquired AmeriCredit Corp for 3.5 billion dollars, Sanofi acquired shares in Genzyme Corporation for 18.5 billion dollars USA, and Intel Corporation bought McAfee for 7.7 billion dollars USA [12].

The acquisition of Anobit Technologies by Apple Inc. was quite large for 500 million dollars, Autonomy Corporation by Hewlett-Packard for 11.7 billion dollars, and the purchase of Vector Aerospace by EADS for 625 million dollars USA [15].

In the last two decades, as a result of the growing internationalization of research, the trend of forming strategic alliances has sharply increased, especially due to the merger of companies in high-tech industries such as pharmaceuticals, telecommunications, semiconductors, etc. These alliances are the most promising form of organization of international scientific and technical cooperation between firms from different countries for the joint solution of scientific and technical problems. Within the framework of following alliances such cooperation between corporations are provided:

- joint R\&D;

- mutual exchange of scientific achievements;

- mutual exchange of production experience;

- training of qualified personnel.

When creating strategic alliances, the emphasis shifts from the acquisition policy to mutually beneficial cooperation, and the risks arising from the implementation of projects are distributed among the partners. As a result, strong scientific and industrial financial structures are formed, the conditions and nature of competition are changing.

To date, the total share of $R \& D$ cooperation alliances is more than half of the joint corporate programs. Significant R\&D expenditures are a significant incentive to form inter-firm alliances to ensure economies of scale, despite the difficulty of coordinating work in this area. The alliances were most developed in the automotive, aircraft, industrial robot, consumer electronics, and more industries. At the same time, it should be noted that alliances are not long-term alliances: $30 \%$ of them end in mergers and 
acquisitions, $40 \%$ cease to exist after the task for which they were created, the other $30 \%$ gradually disintegrate [7].

According to the international classification, strategic alliances are vertical (when cooperating suppliers of factors and companies producing final products) and horizontal (when companies of the same level are involved in joint activities, ie those working in the same field). In horizontal alliances, competing companies cooperate for the benefit of each other. This type of cooperation is typical for companies operating in high-tech industries. For example, the American corporation IBM and the Japanese Toshiba Corporation compete quite actively in the production and sale of laptops, and at the same time they join forces in research and development of flat screens. Prominent examples of companies which are united in strategic alliances and compete at the same time are given in Table 3 [8].

Table 3

Competition and cooperation between partners in strategic alliances in high-tech industries [8]

\begin{tabular}{|c|c|c|}
\hline Alliances & Spheres of cooperation & Spheres of competition \\
\hline $\begin{array}{l}\text { Xerox Corporation and Fuji } \\
\text { Xerox }\end{array}$ & $\begin{array}{l}\text { Most copy technologies, printer } \\
\text { technology }\end{array}$ & $\begin{array}{l}\text { Some copy technologies, } \\
\begin{array}{l}\text { production } \\
\text { components }\end{array} \text { of }\end{array}$ \\
\hline Fujitsu Limited and Amdahl & Universal computer technology & $\begin{array}{l}\text { Distribution of manufactured } \\
\text { products }\end{array}$ \\
\hline IBM and Toshiba Corporation & $\begin{array}{l}\text { Development and production of flat } \\
\text { screens }\end{array}$ & Sales of computers \\
\hline $\begin{array}{l}\text { Sun Microsystems and Fujitsu } \\
\text { Limited }\end{array}$ & $\begin{array}{lr}\text { Research and } & \text { development of } \\
\text { microprocessors, } & \text { computer } \\
\text { technology } & \end{array}$ & $\begin{array}{l}\text { Production of microprocessors, } \\
\text { sales of workstations in Japan }\end{array}$ \\
\hline $\begin{array}{l}\text { Hewlett-Packard and Apple } \\
\text { Inc. }\end{array}$ & $\begin{array}{l}\text { Research and } \\
\text { microprocessors, } \\
\text { transfer }\end{array}$ & Production of microprocessors \\
\hline IBM and Apple Inc. & Computer technology & $\begin{array}{l}\text { Sales of computers and operating } \\
\text { systems }\end{array}$ \\
\hline IBM and Motorola Inc. & $\begin{array}{l}\text { Computer technology, research and } \\
\text { development of microprocessors }\end{array}$ & $\begin{array}{l}\begin{array}{l}\text { Production and sale } \\
\text { microprocessors }\end{array} \\
\end{array}$ \\
\hline
\end{tabular}

From all the above we can conclude that the main motives that push international corporations to create strategic alliances are the following:

- rapid development of technologies and reduction of the life cycle of goods and technological processes, and, accordingly, reduction of time for $\mathrm{R} \& \mathrm{D}$;

- gaining access to scientific and technological achievements of the alliance partner;

- the ever-increasing cost of research in high-tech industries and the distribution of the risk of failure in conducting joint research and development.

It is important to emphasize that the largest TNCs of the Triad countries are characterized by different trends in scientific and technological activities. We have considered the main features of the activities of multinational corporations in the field of R \& D in these countries.

In the United States, much of TNCs' foreign direct investment in production is made through strategic alliances. As mentioned earlier, US companies often become leaders in such alliances. Global companies also form mechanisms for interaction with small firms in the field of R\&D. Some of them (General Electric, Cisco Systems, Inc.) have already made some progress, while others (Procter \& Gamble Co.) are investing heavily in their own R\&D. Their organizational structure is based on the division into basic processes (as a rule, there are $3-5$ processes that underlie the production cycle). The basis of the company is autonomous working groups (teams), the number of which is also minimized. Top management is extremely small and only finances and personnel remain at its disposal. AT\&T Inc., for example, has formed autonomous groups of 10 to 15 people and reduced the number of core processes from 130 to 13. General Electric, which has also begun the transition to the new system, still maintains up to 100 core processes with 9 to 12 people in them.

Considering the features of scientific and technological activities of TNCs in Japan, it should be noted that in the mid-80's began the process of "erosion" of traditional financial groups in Japan and the convergence of Japanese TNCs with existing ones in the US and Western Europe. The current trend is that 
high-tech companies are actively merging with European and American corporations, often becoming a decisive factor in growth (as in the case with the alliance of Fujitsu Limited and Siemens AG). But Japanese corporations are usually more closed and conservative, and prefer to concentrate almost all research activities in centers located in Japan, involving foreign $R \& D$ - laboratories only in the final stages of commercialization of innovations to adapt the finished product or technology to local standards, for its completion taking into account the peculiarities of the local market.

In the analysis of European TNCs can be identified a number of trends, some of which are different from the world. European corporations have a tendency to confront each other, while American and Japanese are more willing to compromise and ally even with their competitors. However, in recent years there has been a growing tendency to unite European corporations in the face of overseas rivals [13]. For example, the management of Telecom Italia SPA and Deutsche Telecom announced a merger. The deal was valued at 79 billion dollars. The new corporation earned 63 billion dollars and a market value of 200 billion dollars, which allowed it to become a worthy competitor to such telecommunications giants as, for example, the American AT\&T Inc.

European corporations, taking advantage of the benefits of the European Union, often place their R \& D laboratories in the country of Europe, where highly qualified personnel are concentrated. For example, ABB Corporation, which emerged from the merger of ASEA (Sweden) and Brown, Boveri \& Cie. (Switzerland), created a new energy research center, but not in Sweden and not in Switzerland, but in Germany, where it was possible to find highly qualified specialists.

Conclusions. In conditions of fierce competition in both international and domestic markets, the ability of companies to operate and develop depends on their ability to create and implement innovations. It is innovations that cause continuous economic change, contribute to the dynamic development and increase the efficiency of both the economic system as a whole and individual enterprise. The scientific and technological development of corporations is a crucial prerequisite for ensuring their profitability. Today, TNCs seek to take advantage of economies of scale in the organization of research and development: globalization allows the costs associated with the creation of new product models to be distributed among more consumers, thereby reducing unit costs or increasing their efficiency. In addition, globalization creates ample opportunities for the use of the international labor division in the scientific field.

\section{REFERENCES:}

1. Porter, M. E. (1998). Competitive Strategy: Techniques for Analyzing Industries and Competitors. New York, Free Press.

2. Kotler, P. \& Keller, K. (2018). Marketing management. 16th ed. Upper Saddle River, N.J Prentice Hall.

3. Nelson, R. (1993). National Innovation System. A Comparative Analysis. Oxford, Oxford University Press.

4. Biloshapka, V. (2008). A Management Effectiveness in International Business. Kyiv National Economic University, Kyiv, Ukraine.

5. Cherneha, O. \& Bocharova, Yu. (2011). Competitiveness of the national economy: civilization dimensions and peculiarities of management in the conditions of globalization: monograph. Eastern Publishing House, Donetsk, Ukraine.

6. UNCTAD (2019). World Investment Report 2019. Investment and the Digital Economy. Retrieved 05 January 2020 from http://unctad.org/en/ PublicationsLibrary/wir2017_en.pdf (Accessed 15 Sep 2020).

7. OECD (2020). New Patterns of Industrial Globalization. Cross-border Mergers and Acquisitions and Strategic Alliances. OECD-Organization for Economic Cooperation and Development. Science, Technology and Industry Outlook 2010-2019. Retrieved 10 September 2020 from http://www.oecdilibrary.org/industry-and-services/new-patterns-of-industrial-globalisation_978926324192911-en (Accessed 10 Sep 2020).

8. OECD (2020). Science, Technology and Innovation Outlook 2019. OECD-Organization for Economic Cooperation and Development. Retrieved 10 September $2020 \mathrm{http}: / /$ www.oecd.org/sti/oecdscience-technology-and-innovation-outlook-2518616337.htm (Accessed 12 Sep 2020).

9. Abdul-Jalal, H., Toulson, P. \& Tweed, D. (2013). "Knowledge Sharing Success for Sustaining Organizational Competitive Advantage". Procedia Economics and Finance, vol. 7, pp. 150-157.

10. Putthiwanit, C. (20 October 2019). "Exploring the impact of organizational culture on employees in multinational enterprise: A qualitative approach". Procedia - Social and Behavioral Sciences, vol. 207, 
pp. 483-491.

11. Rzepka, A. (2017). "Inter-organizational relations as a one of sources of competitive advantage of contemporary enterprises in the era of globalization". Procedia Engineering. vol. 174, pp. 161-170.

12. Petrović-Ranđelović, M., Stevanović, T., \& Ivanović-Đukić, M. (2019). "Impact of Corporate Social Responsibility on the Competitiveness of Multinational Corporations". Procedia Economics and Finance, vol. 25, pp. 332-341.

13. Markusen, J. R. (1998), "Multinational firms, location and trade". The World Economy, vol. 21, issue 6, pp. 733-756.

14. Petersen, B. \&Welch L.S. (2019). "International business development and the internet, posthype". Management International Review, vol.2(77), pp. 7-27. DOI: https://doi.org/10.1007/978-3-66301562-81_2

15. Chaminade, C. \& Vang, J. (2018). "Globalization of knowledge production and regional innovation policy: Supporting specialized hubs in the Bangalore software industry". Research Policy, vol. 37, pp.1684-1696.

УДК 339.137: 339.92

JEL F01, F29, O32, O33

Безрукова Наталія Валеріївна, кандидат економічних наук, доцент. Свічкарь Віталій Анатолійович, кандидат економічних наук, доцент. Сологуб Руслан Валерійович, магістрант. Національний університет «Полтавська політехніка імені Юрія Кондратюка». Науково-технологічна діяльність ТНК: сучасні тенденції та перспективи розвитку. Розглянуто особливості науковотехнологічної діяльності транснаціональних корпорацій, виокремлено основні тенденції й перспективи їх розвитку. Зокрема, наголошено, що джерелом сучасного розвитку суспільства та діяльності людини $є$ інноваційна діяльність, а відповідно інновації стають важливим інструментом усіх радикальних змін у розвитку людини і економічної системи в цілому. Науково-технологічний розвиток транснаціональних корпорацій виступає вирішальною передумовою у забезпеченні їхньої прибуткової діяльності. Досліджено особливості організації НДДКР у транснаціональних корпораціях. Наведено динаміку витрат окремих провідних ТНК на НДДКР. Зазначено, що глобальний характер конкуренції не лише робить нововведення більш значущими для ТНК, але й зумовлює необхідність пошуку нових шляхів створення інновацій. Визначено основні типи здійснення технологічної політики, виділено причини централізації та децентралізації НДДКР, а також можливі ризики, котрі виникають при реалізації цих політик. Досвід розвинених країн свідчить, що конкурентоспроможність забезпечується низкою умов, головними з яких є накопичений науково-технічний потенціал, інституціональні чинники технологічного прогресу та наявність великих наукомістких корпорацій. Тому сучасною тенденцією науково-технологічної діяльності ТНК $\epsilon$ нова хвиля операцій злиття та поглинання (M\&A). Наведено наймасштабніші операції зі злиття й поглинання на початку XXI століття. В останні два десятиліття, як наслідок зростаючої інтернаціоналізації науково-дослідних робіт, різко посилилася тенденція до утворення стратегічних альянсів, особливо за рахунок об'єднання в альянси компаній в таких високотехнологічних галузях, як фармацевтика, телекомунікації, виробництво напівпровідників і т. п. Окрему увагу приділено аналізу причин утворення стратегічних альянсів. Показано, що в окремих випадках конкуренти стають партнерами по стратегічних альянсах у високотехнологічних галузях. Як висновок зазначено, що в умовах жорсткої конкуренції як на міжнародних, так і на вітчизняних ринках здатність компаній функціонувати та розвиватися залежить від їхньої спроможності створювати й упроваджувати інновації. Саме вони зумовлюють безперервні економічні зміни, сприяють динамічному розвиткові та підвищенню результативності як економічної системи в цілому, так $\mathrm{i}$ окремих підприємств. Науково-технологічний розвиток корпорацій є головною передумовою забезпечення та підвищення їх міжнародної конкурентоспроможності.

Ключові слова: науково-технологічна діяльність, транснаціональні корпорації, міжнародна конкуренція, інновації, технологічна політика.

UDC 339.137: 339.92

JEL F01, F29, O32, O33

Bezrukova N.V., PhD (Economics), Associate Professor, Associate Professor. Svichkar V.A., PhD (Economics), Associate Professor. Solohub R.V., Master-Student. National University «Yuri Kondratyuk 
Poltava Polytechnic». Scientific and technological activities of TNC: current trends and prospects. In the article the authors consider the features of scientific and technological activities of transnational corporations, highlight the main trends and prospects for its development. In particular, it is emphasized that the source of modern development of society and human activity is innovation, and accordingly innovation becomes an important tool for all radical changes in human development and the economic system in general. Scientific and technological development of transnational corporations is a crucial prerequisite for ensuring their profitable activities. The purpose of the article is to analyze current trends and prospects for the development of scientific and technological activities of transnational corporations. The article examines the features of the R \& D organization in multinational corporations. The dynamics of expenditures in individual leading TNCs on R\&D is given. It is noted that the global nature of competition not only makes innovations more significant for TNCs, but also necessitates the search for new ways to innovate.

The paper identifies the main types of technological policy, identifies the reasons for the centralization and decentralization of $\mathrm{R} \& \mathrm{D}$, as well as possible risks that arise in the implementation of these policies. The experience of developed countries shows that competitiveness is ensured by a number of conditions, the main of which are the accumulated scientific and technological potential, institutional factors of technological progress and the presence of large knowledge-intensive corporations. Therefore, the current trend of scientific and technological activities of TNCs is a new wave of mergers and acquisitions (M\&A). The authors present the largest mergers and acquisitions at the beginning of the XXI century. In the last two decades, as a result of the growing internationalization of research, the trend of forming strategic alliances has sharply increased, especially due to the merger of companies in such high-tech industries as pharmaceuticals, telecommunications, semiconductors, etc. Special attention is paid to analysis of the reasons for the formation of strategic alliances. It is shown that in some cases competitors become partners in strategic alliances in high-tech industries.

In conclusion, it is noted that in conditions of fierce competition in both international and domestic markets, the ability of companies to operate and develop depends on their ability to create and implement innovations. It is innovations that cause continuous economic change, contribute to the dynamic development and increase the efficiency of both the economic system as a whole and individual enterprise. The scientific and technological development of corporations is the main prerequisite for ensuring and increasing their international competitiveness.

Keywords: scientific and technological activity, transnational corporations, international competition, innovations, technological policy 